\title{
Microstructure and Mechanical Properties of Fe-36Ni and 304L Dissimilar Alloy Lap Joints by Pulsed Gas Tungsten Arc Welding
}

\author{
Qian Wang ${ }^{1,2}$, Junqi Shen ${ }^{1,2, *}$, Shengsun $\mathrm{Hu}^{1,2}$, Guancheng Zhao ${ }^{1,2}$ and Jie Zhou ${ }^{1,2}$ \\ 1 Tianjin Key Laboratory of Advanced Joining Technology, Tianjin University, Tianjin 300354, China; \\ wqtju@tju.edu.cn (Q.W.); huss@tju.edu.cn (S.H.); zgclive@tju.edu.cn (G.Z.); zhoujie33244@163.com (J.Z.) \\ 2 School of Materials Science and Engineering, Tianjin University, Tianjin 300354, China \\ * Correspondence: shenjunqi@tju.edu.cn; Tel./Fax: +86-22-85356746
}

Received: 15 June 2020; Accepted: 3 September 2020; Published: 10 September 2020

\begin{abstract}
High-quality joining of dissimilar alloys between Fe-36Ni alloy and 304L stainless steel is essential in the manufacturing of LNG tanker. In this study, lap joints of Fe-36Ni and 304L dissimilar alloys were fabricated by a pulsed gas tungsten arc welding (P-GTAW) process. The effects of low-frequency pulse on the appearance, microstructure and mechanical properties of the Fe-36Ni/304L lap joints was investigated. With the increase of frequency, the feature sizes of $\alpha$ (the transition angle of the upper surface of Fe-36Ni to the surface of the weld bead) and $\mathrm{R}$ (shortest distance between weld root and weld surface) exhibited downtrend and uptrend, respectively, while $\mathrm{La}$ (the maximum weld width of lower sheet) and $\mathrm{P}$ (the maximum weld penetration of lower sheet) changed in a smaller range. Fusion zone (FZ) is mainly composed of $\gamma$ phase and $\mathrm{M}_{23} \mathrm{C}_{6}$ during solidification, and $\mathrm{M}_{23} \mathrm{C}_{6}$ particles are distributed on the grain boundaries of the cells, which reduced the mechanical properties of joint. The average hardness between $110 \mathrm{HV}_{1}$ and $136 \mathrm{HV}_{1}$ is lower than that of the base metals. Fractures of all joints located at the Fe-36Ni side near the weld, and a dimple fracture in all samples indicated a ductile fracture. This study found that the heat input values remain $198.86 \mathrm{~J} \mathrm{~mm}^{-1}$ and increased pulse frequency can improve the maximum tensile force. The average maximum tensile force of the lap weld is $11.95 \mathrm{kN}$ when pulsed frequency is $15 \mathrm{~Hz}$.
\end{abstract}

Keywords: P-GTAW; dissimilar alloy; grain refinement; mechanical properties

\section{Introduction}

In recent years, the scale of the liquid natural gas (LNG) transportation market increased with increased international demand for LNG, which poses new challenges to the design of LNG carrying capacity. The maintenance system of the LNG ship tanker is the most critical part. Its function is to store the LNG with a liquid temperature of $-163{ }^{\circ} \mathrm{C}$ [1]. Therefore, the materials selected for the maintenance system must be safe in cryogenic environments. Fe-36Ni alloy with face-centered cubic (FCC) crystal structure, famous as invar alloy, has a very low linear expansion coefficient in the temperature range below Curie $\left(230^{\circ} \mathrm{C}\right)$. Fe-36Ni is the perfect insulation material for LNG maintenance system. 304L is an economical austenitic stainless steel with the excellent corrosion resistance and low temperature toughness, which can effectively prevent the occurrence of malignant brittle fracture accidents. Nowadays, Fe-36Ni and 304L have been widely used in building of LNG ships and LNG-related industries [2-6].

Fe-36Ni is austenitic steel, mainly composed of Fe and Ni. The composition and structure of Fe-36Ni were similar to typical nickel-based alloys. Therefore, the welding problem of nickel-based alloy and austenitic stainless steel had guiding significance for this study. Shakil et al. [7], reported that 
there were a few micro-cracks in the fusion zone during the welding process of 304L and Inconel 625 dissimilar alloys. During the solidification of nickel alloy, $\mathrm{Ni}, \mathrm{S}$, and $\mathrm{P}$ formed liquid state membrane with low melting points respectively. In the late solidification, liquid state membrane was subjected to tensile stress and thus lead to hot cracks [8,9]. Ni et al. [10], successfully connected invar steel via laser welding technology. It is found that the lap joint had a lower hot crack sensitivity than the butt joint, because the cracked liquid state membrane of the lap joint during solidification can obtain the filler from the upper molten pool metal. Furthermore, there will be brittle phase precipitation in the welding seam due to the different chemical composition of dissimilar metals, which decreased the joint mechanical property [11-14]. Lee et al. [15], found faster cooling rates could inhibit the precipitation of chromium carbides in the fusion zone when welding 690 alloy and 304L dissimilar alloys. However, as far as the author knows, researchers mainly focused on the relationship between microstructure and mechanical properties when welding dissimilar metals, and often ignore the influence of macro morphology on joint performance. The macro morphology of the weld also had an important influence on the mechanical properties of the weld. Guo et al. [16], found that the tensile fracture load of 301L lapping laser welded joint increased with the increase of weld width. Wang et al. [17], found that the effective connection area was proportional to the maximum tensile force by lapping the $0.7 \mathrm{~mm} / 1.0 \mathrm{~mm}$ Fe-36Ni alloy sheets via pulsed gas tungsten arc welding (P-GTAW). P-GTAW can accurately control arc capacity and distribution by adjusting welding parameters of pulse specification, which reduced the influence of heat accumulation of welding parts to control weld forming [18].

P-GTAW had been used to weld dissimilar alloys. Moganraj et al. [19], used continuous current GTAW and pulsed argon tungsten arc welding to achieve the welding of AISI 4340 and AISI 304L. In the tensile performance test, it was found that the 4340/304L dissimilar joint using P-GTAW has better tensile performance. Ramkumar et al. [20], used P-GTAW to achieve the connection of Monel 400 and Hastelloy C276 dissimilar metals. It is found that P-GTAW can reduce the segregation rate of Mo, inhibit the occurrence of intermetallic compounds, and improve the mechanical properties of the joint by controlling the heat input and cooling rate. According to the above, P-GTAW is characterized by precise control of the weld geometry and inhibition of the precipitation of the brittle phase in the weld. Therefore, this research used pulsed tungsten argon arc welding to weld Fe-36Ni and 304L.

In this study, the effects of the pulse frequency on the weld formation of Fe-36Ni/304L lap joints was systematically studied and analyzed the microstructure evolution behavior and mechanical properties of the welded joints.

\section{Experimental Procedure}

Two base materials used in this study were Fe-36Ni and 304L alloys, respectively. The dimensions of Fe-36Ni and 304L alloys were $350 \mathrm{~mm} \times 100 \mathrm{~mm} \times 0.7 \mathrm{~mm}$ and $350 \mathrm{~mm} \times 100 \mathrm{~mm} \times 2 \mathrm{~mm}$, respectively. The chemical compositions of the two materials are shown in Table 1.

Table 1. Nominal chemical compositions (wt\%) of Fe-36Ni alloy and 304L stainless steel.

\begin{tabular}{ccccccccc}
\hline Element & $\mathbf{C}$ & $\mathbf{P}$ & $\mathbf{S}$ & $\mathbf{S i}$ & $\mathbf{M n}$ & $\mathbf{N i}$ & $\mathbf{C r}$ & $\mathbf{F e}$ \\
\hline Fe-36Ni & $\leq 0.05$ & $\leq 0.02$ & $\leq 0.02$ & $\leq 0.2$ & $0.2-0.6$ & $35.0-37.0$ & - & Bal \\
304L & 0.03 & 0.04 & 0.03 & 0.75 & 2 & $8.0-12.0$ & $18.0-20.0$ & Bal \\
\hline
\end{tabular}

As shown in Figure 1a, the lap welded joint of dissimilar alloys was fabricated by using the P-GTAW in the vertical upward position. The Fe-36Ni sheet was placed on the $304 \mathrm{~L}$ sheet (transverse direction), and the lap length was $30 \mathrm{~mm}$. The P-GTAW process was performed by using a Fronius Magic Wave 4000 welding power source (Fronius, Wels, Austria). The tungsten electrode with a diameter of $2.4 \mathrm{~mm}$ was positioned as shown in Figure 1b. A Motoman HP6 6-axis robot (Yaskawa Electric, Shanghai, China) was adopted to control the welding speed and path of the GTAW torch. Before welding, the workpieces were cleaned with alcohol to remove the impurities. The welding current and welding voltage were collected by an electric signal acquisition system with a sampling 
frequency of $10 \mathrm{kHz}$. The composition of the acquisition system is similar to that in the reference [21]. According to Joseph et al. [22], the heat input (HI) can be calculated as follow Equation (1).

$$
H I=\frac{\int_{0}^{t} U_{i} I_{i} d t}{t \times v} \times \eta
$$

where $U_{i}$ and $I_{i}$ are instantaneous voltage and current, respectively, $v$ is the welding speed, $\eta$ is the heat transfer efficiency equal to 70\% [23], and $t$ is the sampling time. The main P-GTAW welding parameters and calculated heat input for different welding parameters are shown in Table 2.

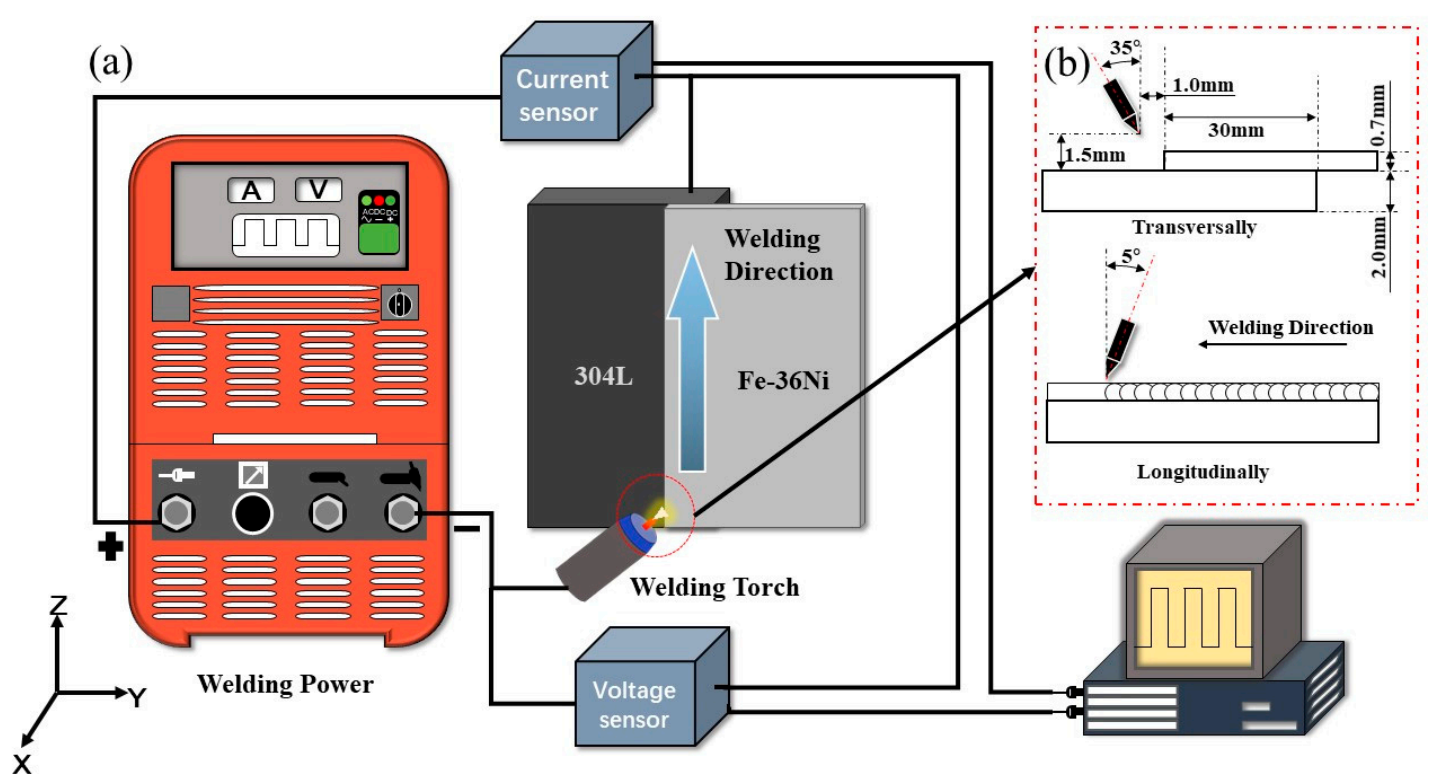

Figure 1. Schematic diagram of (a) welding setup and (b) position of tungsten electrode.

Table 2. Welding parameters and corresponding heat inputs of the P-GTAW process.

\begin{tabular}{|c|c|c|c|c|c|c|}
\hline $\begin{array}{l}\text { Peak } \\
\text { Current/ } \\
\text { (A) }\end{array}$ & $\begin{array}{l}\text { Base } \\
\text { Current/ } \\
\text { (A) }\end{array}$ & $\begin{array}{c}\text { Duty Cycle/ } \\
(\%)\end{array}$ & $\begin{array}{l}\text { Pulse Frequency/ } \\
(\mathrm{Hz})\end{array}$ & $\begin{array}{c}\text { Welding } \\
\text { Speed/ } \\
\left(\mathrm{mm} \cdot \mathrm{min}^{-1}\right)\end{array}$ & $\begin{array}{l}\text { Gas Flow/ } \\
\left(\mathrm{L} \cdot \min ^{-1}\right)\end{array}$ & $\begin{array}{c}\text { Average HI/ } \\
\left(\mathrm{J} \cdot \mathrm{mm}^{-1}\right)\end{array}$ \\
\hline \multirow{6}{*}{100} & \multirow{6}{*}{12} & \multirow{6}{*}{55} & 1 & \multirow{6}{*}{200} & \multirow{6}{*}{15} & 199.48 \\
\hline & & & 3 & & & 202.75 \\
\hline & & & 5 & & & 205.25 \\
\hline & & & 7 & & & 201.47 \\
\hline & & & 10 & & & 197.52 \\
\hline & & & 15 & & & 201.23 \\
\hline
\end{tabular}

As shown in Figure 2, the metallographic specimens cut from the welded joints in three sections (i.e., cross section, parallel section and longitudinal section) were polished and finally etched by an etchant $\left(5 \mathrm{~g} \mathrm{FeCl}_{3}+10 \mathrm{~mL} \mathrm{HNO}_{3}+20 \mathrm{~mL} \mathrm{H}_{2} \mathrm{O}\right.$ ) for $20 \mathrm{~s}$. Four feature sizes (i.e., $\mathrm{La}, \mathrm{P}, \mathrm{R}$ and $\alpha$ ) of the lap joint were measured. As shown in Figure $2 a, L a, P, R$ and $\alpha$ represent the maximum weld width, the maximum weld penetration in the lower sheet, the shortest distance from the weld root to the weld surface, and the transition angle of the upper surface of Fe-36Ni to the surface of the weld bead, respectively. 


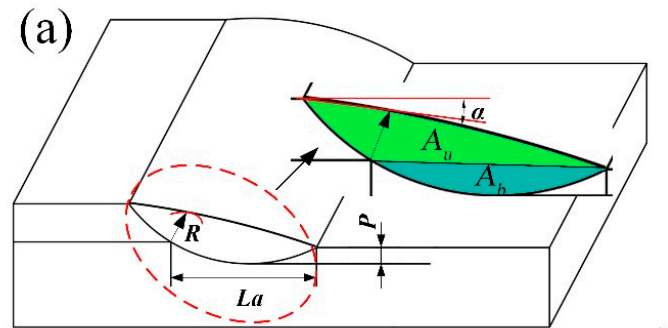

(b)

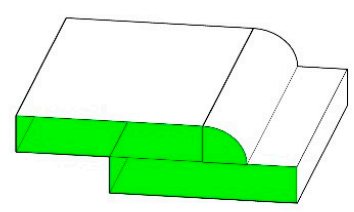

(c)

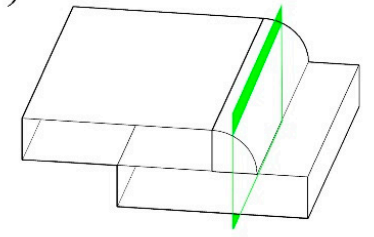

(d)

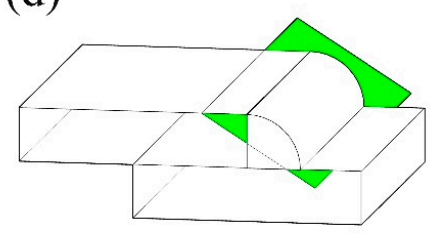

Figure 2. Macroscopical geometry of lap welding section (a) measurement of feature sizes and weld cross-sectional area, (b) cross section, (c) longitudinal section and (d) parallel section.

The microstructure was observed using an OLYMPUS GX51 optical microscope (OM) (OLYMPUS, Tokyo, Japan) and Hitachi S-4800 scanning electron microscope (SEM) (Hitachi, Tokyo, Japan) coupled with an energy dispersive spectrometer (EDS) (Hitachi, Tokyo, Japan). X-ray diffraction (XRD) analysis for phase identification was conducted by a D8 ADVANCE X-ray diffractometer (Bruker, Karlsruhe, Germany) with reflection geometry and $\mathrm{CuK} \alpha$ radiation $(\lambda=0.154 \mathrm{~nm})$. The scanning was made through $2 \theta=30-100^{\circ}$ with a step interval of $0.02^{\circ}$. The phase composition of the weld metal was calculated using Jmatpro software (v 10.0, Sente Software Ltd., Surrey Research Park, Guildford, UK). The hardness test was performed using an HV-1000A micro-hardness tester (Laizhou Huayin Test Instrument Co., Ltd., Yantai, China) with a load of $1000 \mathrm{~g}$ for $15 \mathrm{~s}$, and the distribution of test indentations is shown in Figure 3. Tensile tests were conducted by a CSS-44100 universal testing machine (Changchun New Testing Machine Co., Ltd, Changchun, China) with a loading rate of 2 $\mathrm{mm} / \mathrm{min}$, and the size of tensile samples is shown Figure 4 .

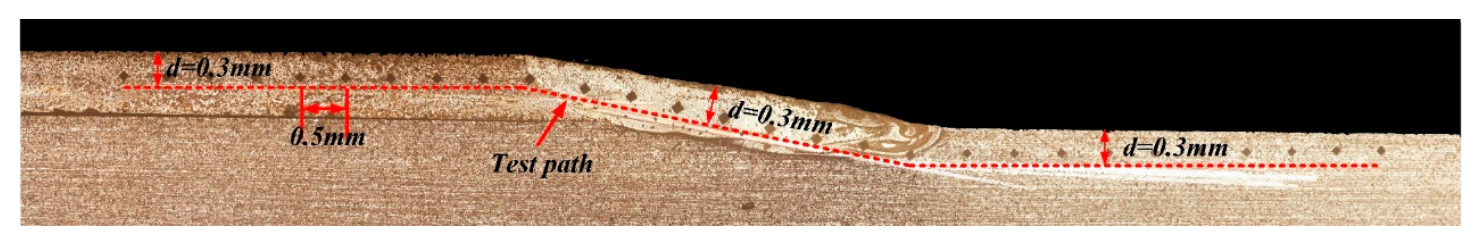

Figure 3. Schematic of hardness test. 


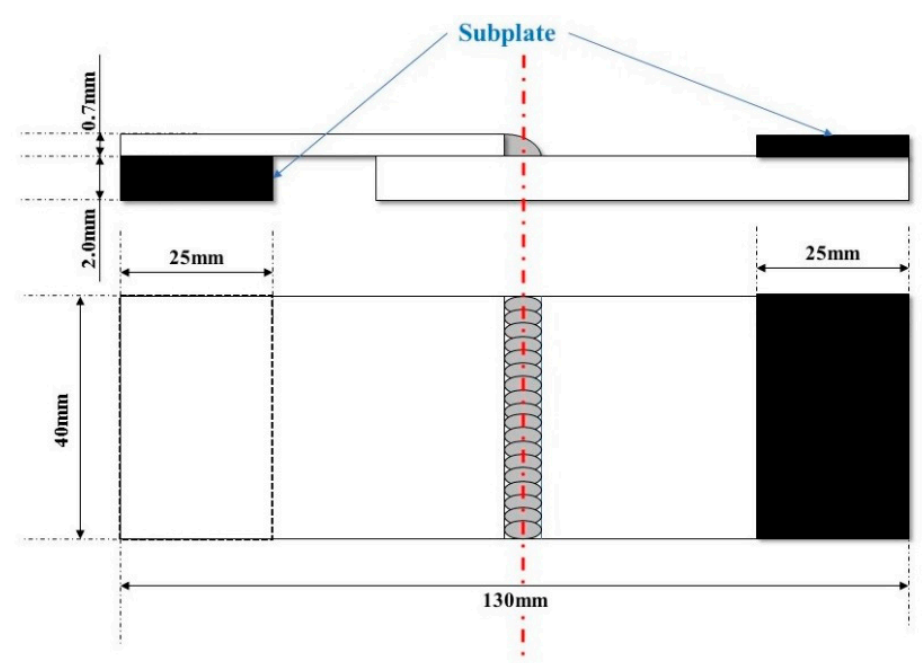

Figure 4. Schematic of tensile sample.

\section{Results and Discussion}

\subsection{Macro-Morphology of the Welded Joints}

Figure 5 shows the macroscopic morphological characteristics of the lap joints obtained at different pulse frequencies, and the welds showed good appearances without oxidation and visible cracks. The surface of the weld was relatively rough at the frequency of $1 \mathrm{~Hz}$, and it became tighter with the increase in the pulse frequency.
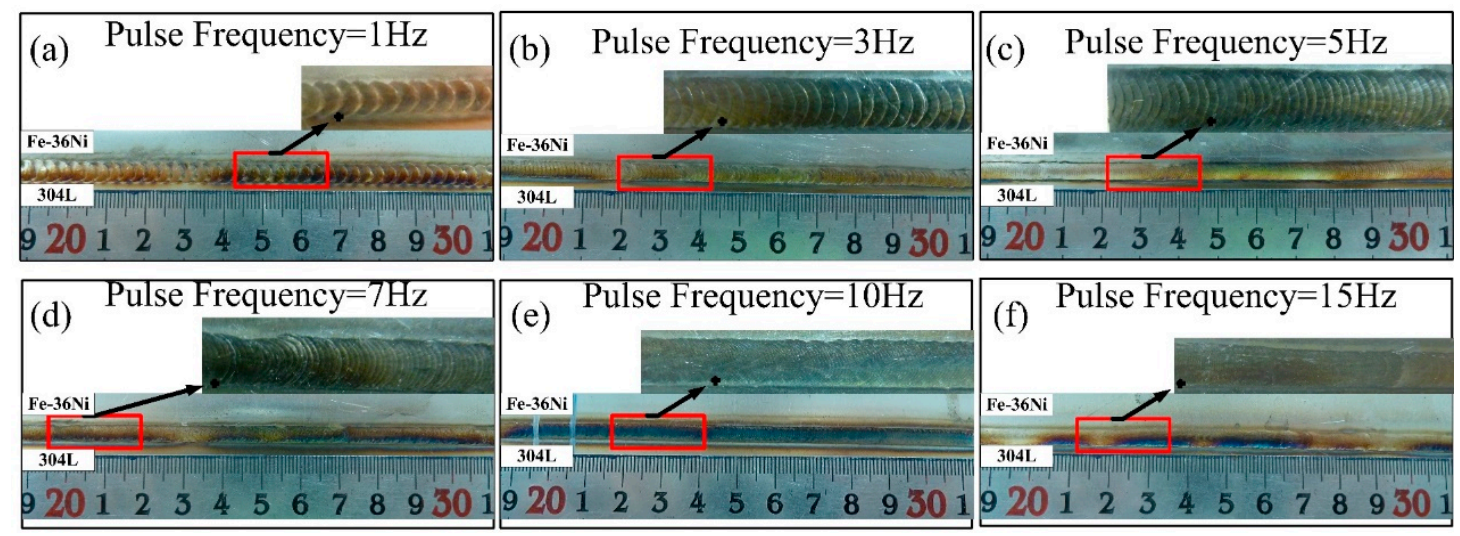

Figure 5. Surface appearance of the weld: (a) $1 \mathrm{~Hz},(\mathbf{b}) 3 \mathrm{~Hz},(\mathbf{c}) 5 \mathrm{~Hz}$, (d) $7 \mathrm{~Hz}$, (e) $10 \mathrm{~Hz}$ and (f) $15 \mathrm{~Hz}$.

The cross-sectional metallographic images of the lap joints at different pulse frequencies are shown in Figure 6, and there are no obvious cracks in the welds. As shown in Figure 7a, the feature size $\alpha$ decrease with the increase of the pulse frequency and $R$ is directly proportional to the pulse frequency. Figure $6 \mathrm{f}$ shows that the smooth transition of the weld surface could be obtained when frequency was $15 \mathrm{~Hz}$. Under this condition, $R$ was $0.69 \mathrm{~mm}$ and $\alpha$ was $0.95^{\circ}$. Figure $7 \mathrm{~b}$ indicates that $L a$ and $P$ changed in a smaller range with the increase of pulse frequency due to the almost constant thermal input at different pulse frequency. The average values of $L a$ and $P$ were $3.37 \mathrm{~mm}$ and $0.37 \mathrm{~mm}$, respectively. 


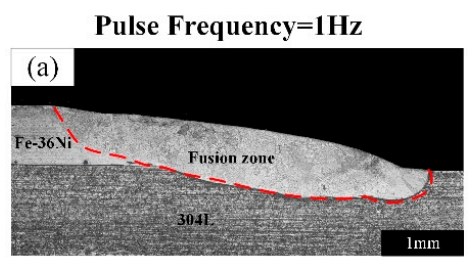

Pulse Frequency $=7 \mathbf{H z}$

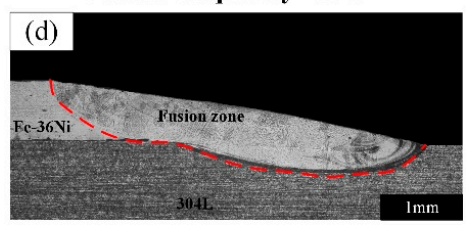

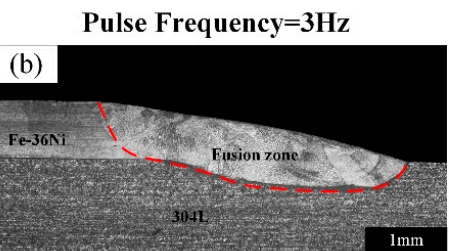

Pulse Frequency $=10 \mathrm{~Hz}$

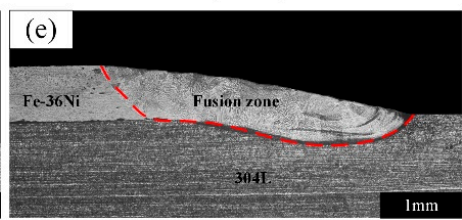

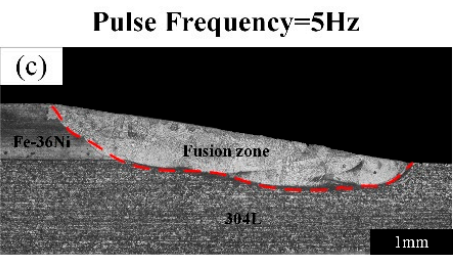

Pulse Frequency $=15 \mathrm{~Hz}$

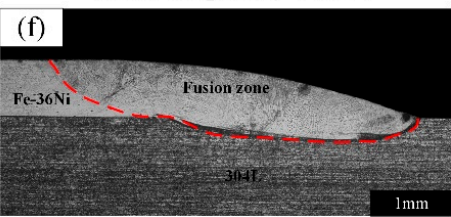

Figure 6. The cross-sectional of the lap joints at different pulse frequencies: (a) $1 \mathrm{~Hz}$, (b) $3 \mathrm{~Hz}$, (c) $5 \mathrm{~Hz}$, (d) $7 \mathrm{~Hz},(\mathbf{e}) 10 \mathrm{~Hz}$ and (f) $15 \mathrm{~Hz}$.

(a)

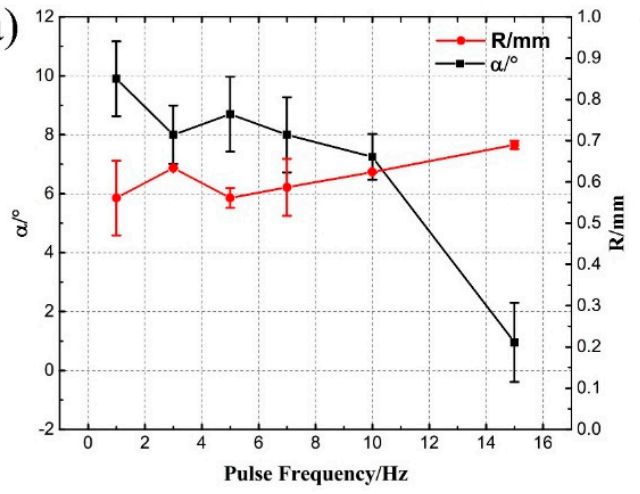

(b)

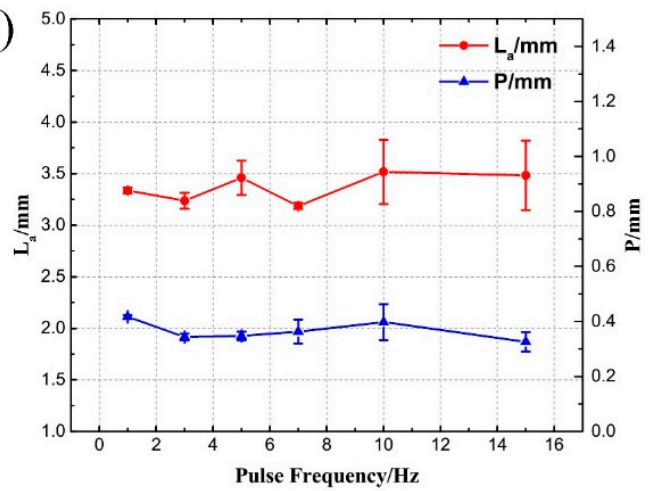

Figure 7. The feature sizes of different pulse frequencies: (a) $R$ and $\alpha,(\mathbf{b}) L a$ and $P$.

Figure 8a-d represent longitudinal section of lap joint, the overall weld penetration depth was different when the pulse frequency was less than $5 \mathrm{~Hz}$ (Figure 8a,b). At peak current stage and the base current stage, the arc acted positions on the weld surface were different when pulse frequency was smaller. At peak current stage, the center of the molten pool was subjected to the largest plasma pressure and the penetration depth was greater. At base current stage, the plasma pressure was reduced, and the penetration depth was smaller [24]. As the pulse frequency increases, the positions of the peak current and the base current in a unit time gradually approach, and the overall weld penetration difference gradually decreases. When the frequency is greater than $10 \mathrm{~Hz}$, the welding process becomes more stable and the heat acted on the weld is more uniform over the unit length of the weld, resulting in a uniform penetration depth (Figure 8c,d). 

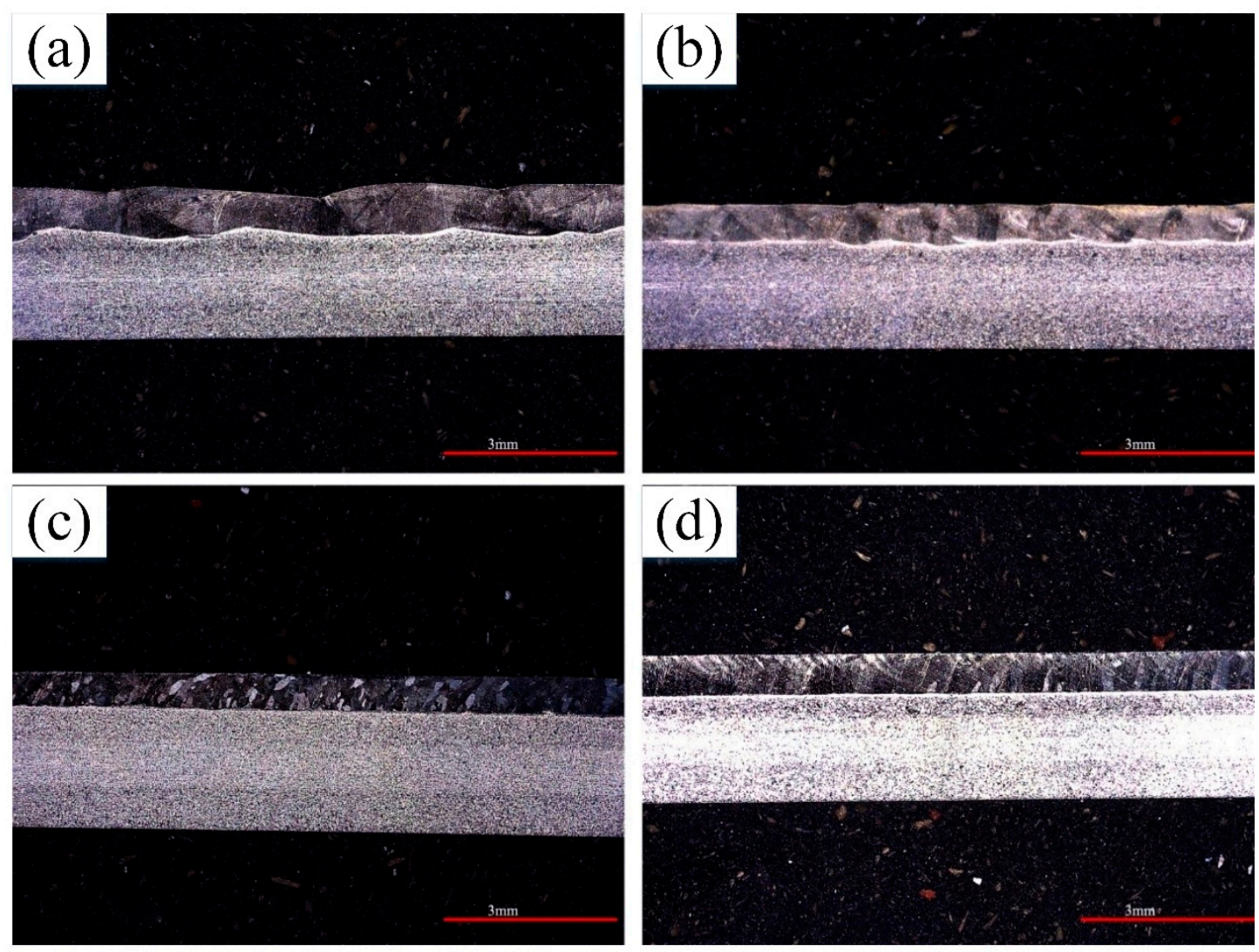

Figure 8. The longitudinal section of the lap joints at different pulse frequencies and schematic of molten pool behavior at different pulse current stages: (a) $1 \mathrm{~Hz},(\mathbf{b}) 3 \mathrm{~Hz},(\mathbf{c}) 10 \mathrm{~Hz}$, (d) $15 \mathrm{~Hz}$.

Figure 9 shows that the parallel section of the lap joints of the weld with different pulse frequencies. Due to the limited dimension of P-GTAW spot, it could be clearly seen that the melting boundary of parallel section was discontinuous and periodical when the pulse frequency was less than $7 \mathrm{~Hz}$ in Figure 9a-c. Inconsistent weld morphology will deteriorate joint property, thus avoid the discontinuous and periodic appearance of the melting boundary as much as possible. The parallel section of the lap joints will change according to different pulse frequency. As is shown in Figure $9 d-f$, continuous weld appearance in the parallel section can be obtained when the pulse frequency was greater than $7 \mathrm{~Hz}$. 

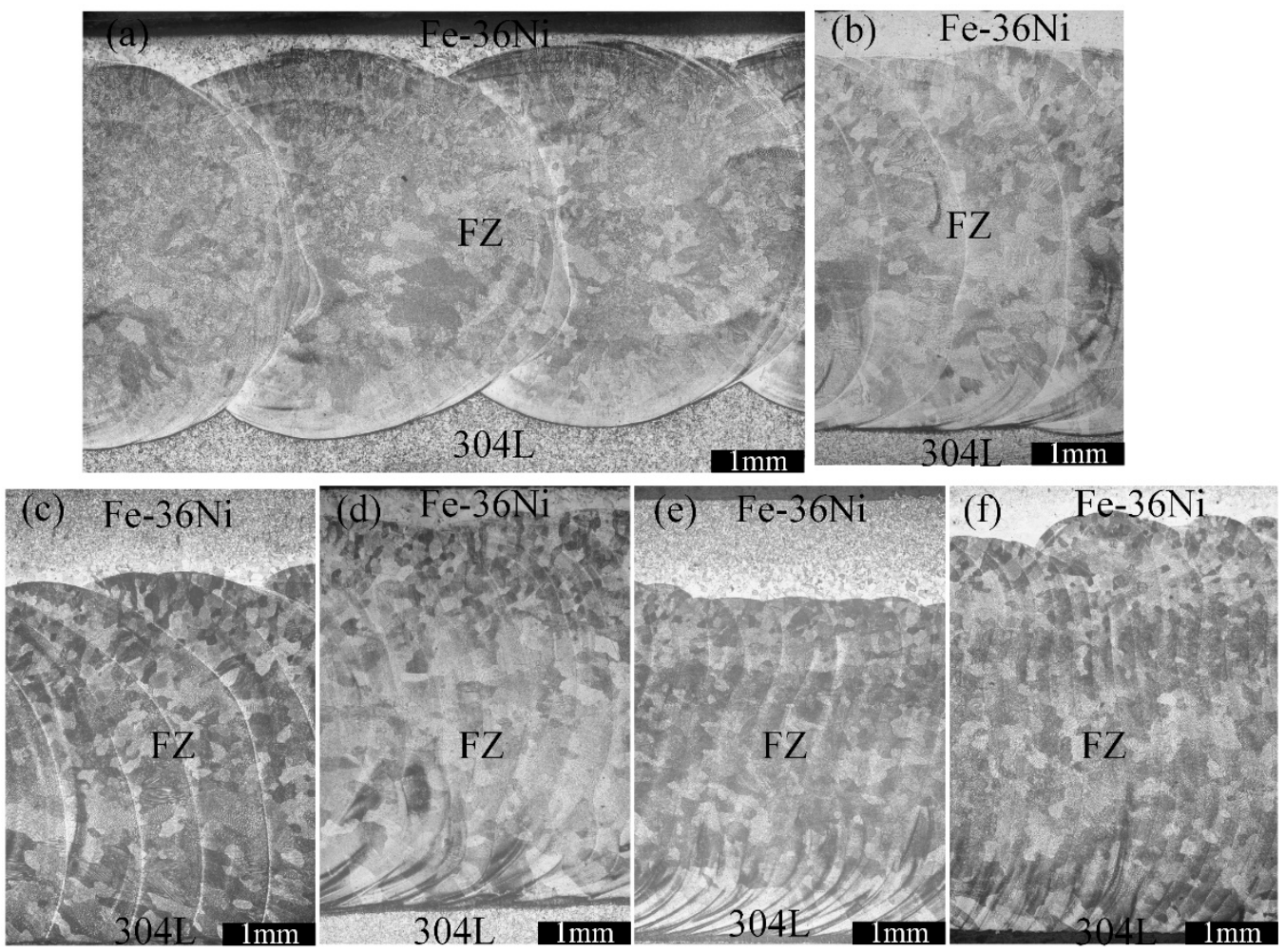

Figure 9. The parallel section of the lap joints at different pulse frequencies: (a) $1 \mathrm{~Hz},(\mathbf{b}) 3 \mathrm{~Hz},(\mathbf{c}) 5 \mathrm{~Hz}$, (d) $7 \mathrm{~Hz},(\mathbf{e}) 10 \mathrm{~Hz},(\mathbf{f}) 15 \mathrm{~Hz}$.

\subsection{Microstructure of the Lap Joints}

Zhang et al. [25], studied the laser welding of dissimilar aluminum alloy lap joints. This research found that the chemical composition of the welded joints can be changed by controlling fusion ratio to reduce the thermal cracking sensitivity of the welded joints. In this study, the fusion ratio is used to calculate the chemical composition of the weld (shown in Figure 2a), and the calculation results were input into the Jmatpro software to calculate the phase composition of the weld. The results of chemical composition were shown in Table 3. It is calculated as follows Equations (2) and (3):

$$
\begin{gathered}
D \% \text { weld }=\left[\frac{A_{\mathrm{u}}}{A_{u}+A_{b}}\right] \\
E \% \text { weld }=(E \% \mathrm{Fe}-36 \mathrm{Ni}) \times D \%+(E \% 304 \mathrm{~L}) \times(1-D \%)
\end{gathered}
$$

where $A_{u}$ is the fusion area of the upper sheet, and $A_{b}$ is the fusion area of the lower sheet, $E \% \mathrm{Fe}-36 \mathrm{Ni}$ and $E \% 304 \mathrm{~L}$ are the content of chemical composition in Fe-36Ni and $304 \mathrm{~L}$, respectively. The increase or decrease of $\mathrm{Cr}$ and $\mathrm{Ni}$ content in weld had great influence on the phase composition of weld [26]. The efficiency of welding test can be improved by using the above method to judge the phase composition in the welding seam.

Table 3. The calculated fusion ratios and chemical compositions of the weld metal (wt $\%$ ).

\begin{tabular}{cccccccc}
\hline Pulse Frequency & $\mathbf{C}$ & $\mathbf{N i}$ & $\mathbf{C r}$ & $\mathbf{F e}$ & $\mathbf{S i}$ & $\mathbf{M n}$ & $\mathbf{D} \%$ \\
\hline 1 & 0.03 & 27.50 & 6.89 & 63.46 & 0.38 & 0.80 & 0.66 \\
3 & 0.03 & 27.73 & 6.73 & 63.40 & 0.37 & 0.78 & 0.67 \\
5 & 0.03 & 27.12 & 7.15 & 63.57 & 0.39 & 0.82 & 0.65 \\
7 & 0.03 & 28.69 & 6.06 & 63.12 & 0.36 & 0.72 & 0.71 \\
10 & 0.03 & 28.56 & 6.15 & 63.161 & 0.36 & 0.73 & 0.71 \\
15 & 0.03 & 30.0 & 5.09 & 62.7 & 0.33 & 0.63 & 0.76 \\
\hline
\end{tabular}


The SEM-EDS results showed that the weld metal at $10 \mathrm{~Hz}$ was composed of $1.22 \mathrm{wt} \% \mathrm{C}, 4.58$ $w t \% \mathrm{Cr}, 64.42 \mathrm{wt} \%$ Fe and $29.78 \mathrm{wt} \% \mathrm{Ni}$. By comparing the results in the Table 3, it is found that the accuracy of the calculated chemical composition in the weld metal was high.

According to the results in the Table 3, the phase content of the weld metal was calculated via the Jmatpro software. The Jmatpro results displayed that the melting zone was mainly composed of $\gamma$ phase and carbide with the contents of $98.67 \%$ and $1.33 \%$, respectively. As shown in Figure 10, the weld metal was mainly composed of austenite and $\mathrm{M}_{23} \mathrm{C}_{6}$, which was consistent with the calculation results based on the Jmatpro software.

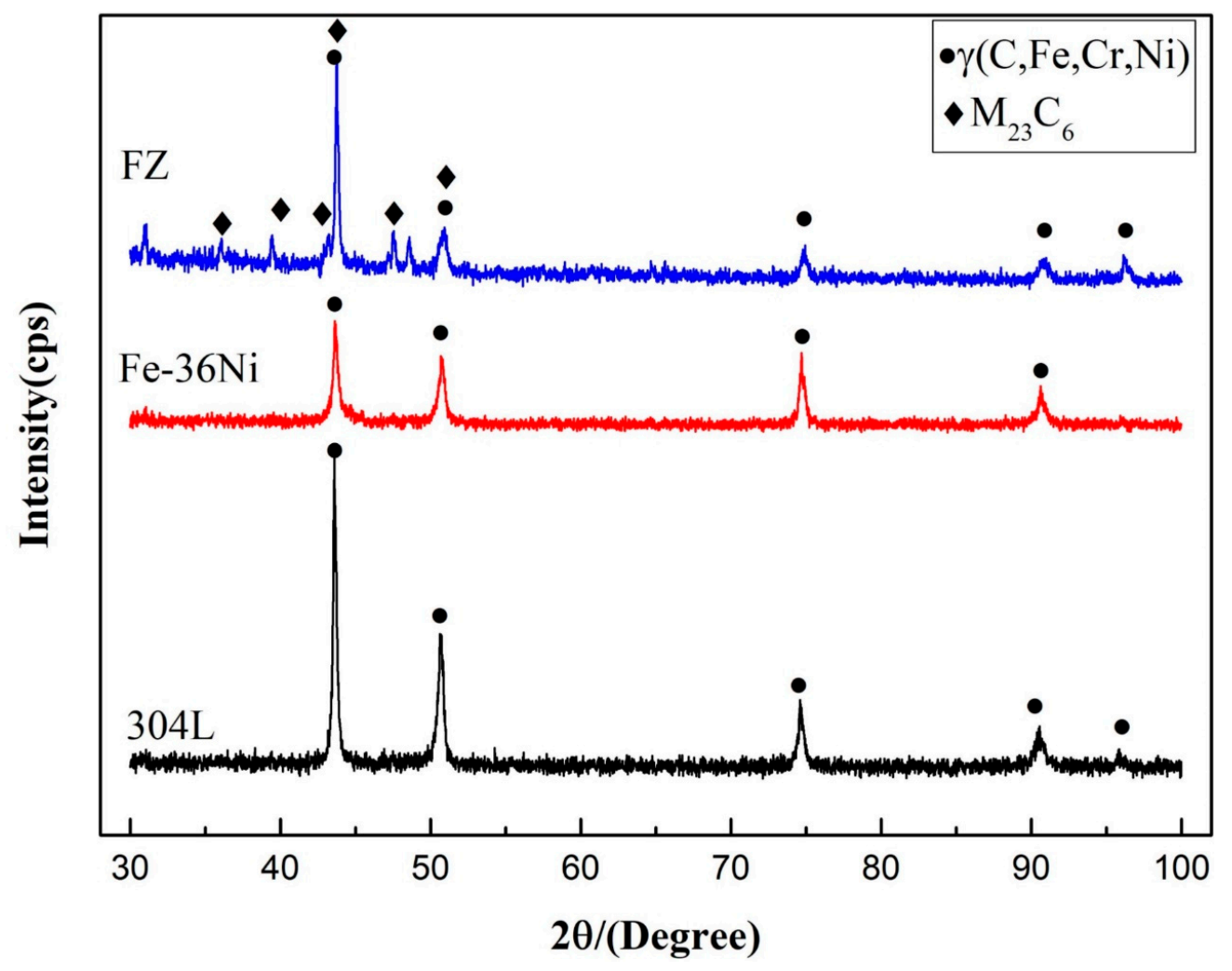

Figure 10. XRD pattern of the lap joint at frequency of $10 \mathrm{~Hz}$.

Figure 11 shows the microstructure of the dissimilar lap joint at $10 \mathrm{~Hz}$, and the fusion zone consisted of austenite. The substructure of the fusion zone showed columnar dendrites and cellular crystal, as shown in Figure 12.
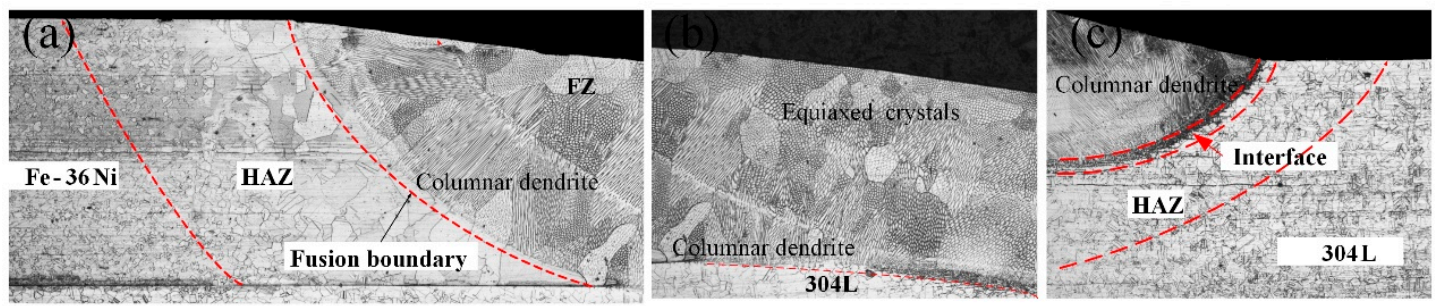

Figure 11. The cross-sections of joints at $10 \mathrm{~Hz}$ : (a) Fe-36Ni side (b) FZ and (c) 304L side. 


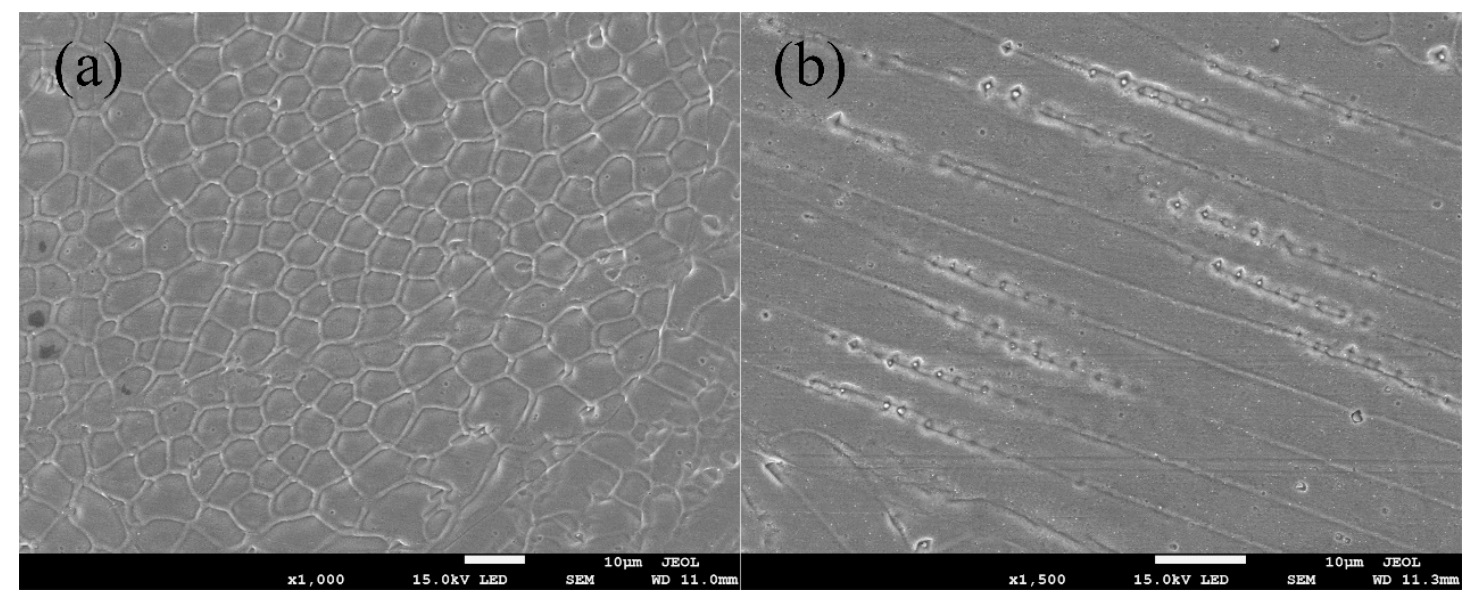

Figure 12. The substructure of FZ: (a) Cellular crystal, (b) Columnar dendrite.

The researchers [27], summarized the effects of temperature gradient $G$ and growth rate $R$ on the solidification structure of the alloy. It was found that the most important parameter affecting the solidification form was $G / R$. According to Equation (4). When the molten pool is crystallized, the melting boundary preferred starts to crystallize. The solidification mode will move from planar to cellular, cellular and columnar dendrites, and finally to equiaxed crystals with the temperature gradient decreases. As shown in Figure 11a,c, columnar crystals grow towards the weld center at the fusion boundary. In addition, there are equiaxed crystals at the top of the weld as shown in Figure 11b, because the $G$ decreases with the increase of distance from the fusion line which resulting in $G$ is small in the weld center.

$$
\frac{G}{R} \geq \frac{\Delta T}{D_{L}}
$$

where $\Delta T$ is the temperature difference across the interface layer, and $D_{L}$ is the diffusion coefficient.

As shown in Figure 11a,b, the width of the heat affected zone (HAZ) in Fe-36Ni side was greater than that in $304 \mathrm{~L}$ side. This is because the thermal conductivity of Fe-36Ni $\left(4.63 \mathrm{~W} \mathrm{~m}^{-1} \mathrm{~K}^{-1}\right)$ is less than that of $304 \mathrm{~L}\left(16.3 \mathrm{~W} \mathrm{~m}^{-1} \mathrm{~K}^{-1}\right)$. During the welding process, the temperature gradient in the Fe-36Ni side was steeper than that in the $304 \mathrm{~L}$ side, leading to the obvious grain growth in the HAZ in Fe-36Ni side.

Figure 13 is a low magnification SEM micrograph at the fusion boundaries. There was epitaxial growth near the fusion boundary on the Fe-36Ni side, and new grains nucleated at the fusion boundary. The composition of the weld metal on the $304 \mathrm{~L}$ side was quite different from that of the base metal, so the weld metal was crystallized in a non-epitaxial manner at the melting boundary. There is a transition zone at the interface between 304L and FZ. Ding et al. [28], studied the microstructure of $9 \% \mathrm{Cr} / \mathrm{CrMoV}$ dissimilar welded joints. It was found that the transition zone was caused by the difference in the content of $\mathrm{Cr}$ element between the $\mathrm{FZ}$ and $9 \% \mathrm{Cr}$ base materials. 

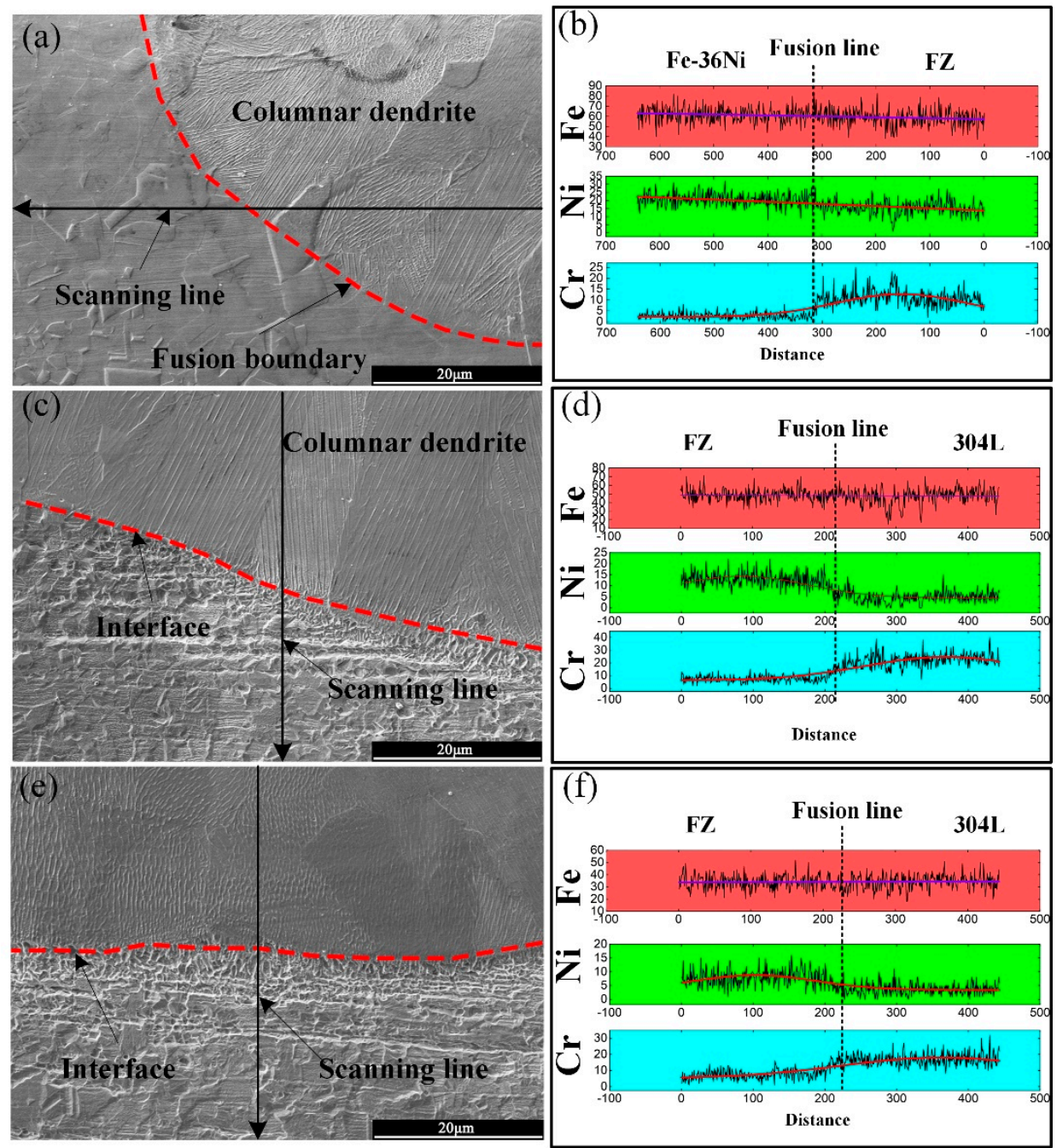

Figure 13. EDS linear analysis near the fusion boundaries at $10 \mathrm{~Hz}$ : (a) Fe-36Ni alloy side, (b) area near the weld root of $304 \mathrm{~L}$, (c) area near the welding toe of $304 \mathrm{~L}$, (d) linear elements distribution of Fe-36Ni side, (e) linear elements distribution of area near the weld root of $304 \mathrm{~L}$ and (f) linear elements distribution of area near the welding toe of $304 \mathrm{~L}$.

Because Fe-36Ni and 304L have obvious differences in composition, and the composition of the FZ is also different from any other base material. The $\mathrm{Ni}$ content and $\mathrm{Cr}$ content in the Fe-36Ni alloy 304L are relatively high, respectively, The $\mathrm{Ni}$ and $\mathrm{Cr}$ contents showed a significant change at the fusion boundary. Figure 13b,d,f shows the liner EDS results of $\mathrm{Fe}, \mathrm{Cr}$ and Ni elements at the three positions of lap joint. In area of Fe-36Ni to FZ, the Cr content changes greatly, and no transition layer appears. In area of FZ to $304 \mathrm{~L}$, an analysis of the EDS linear distribution showed similar characteristics, Cr content increased, and Ni content decreased.

The metallographic photographs of the weld center in the parallel section are shown in Figure 14 and all the FZs were composed of equiaxial crystals. Image software was used to measure the average grain size, and the results showed that the average grain size decreased with the increase of pulse frequency. The reasons for the grain refinement caused by increasing the pulse frequency are usually as follows. With the pulse frequency increased, the numbers of the plasma flow force on the molten pool per unit time increased, which caused strong electromagnetic stirring in the molten pool, breaking the dendrites and increasing the nucleation sites, and eventually increasing the grain numbers in the FZ [29-31]. But this does not mean that simply increasing the pulse frequency can always refine the grains, and too high welding pulse frequencies will cause the weld structure deterioration. Shao et 
al. [32], reported that too high a pulse frequency reduced the mechanical properties of the welded joint. Because the effect of the pulse current is too strong in the molten pool at a higher welding frequency. The molten pool cannot form a disordered dendrite arrangement, resulting in the area of equiaxed grains in the center of the weld reduced. In this study, the grain size of the weld center at the pulse frequency of $15 \mathrm{~Hz}$ was 35\% smaller than that at the pulse frequency of $1 \mathrm{~Hz}$.

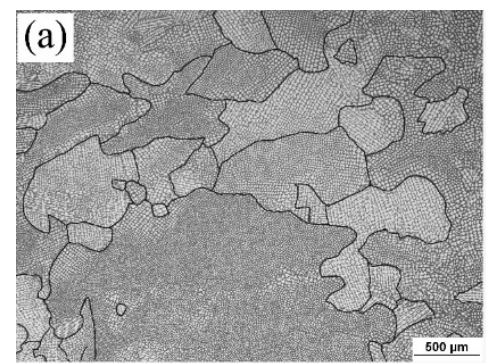

$\mathrm{D}=559.90 \mu \mathrm{m}$

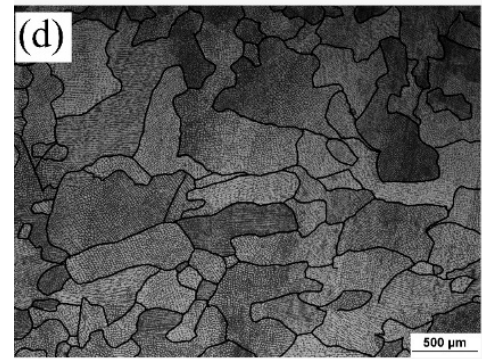

$\mathrm{D}=470.31 \mu \mathrm{m}$

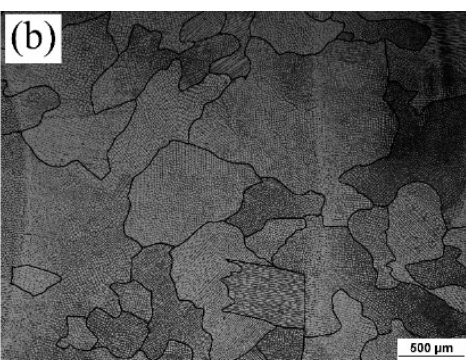

$\mathrm{D}=543.68 \mu \mathrm{m}$

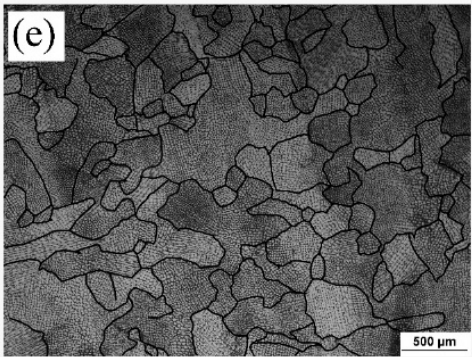

$\mathrm{D}=406.43 \mu \mathrm{m}$

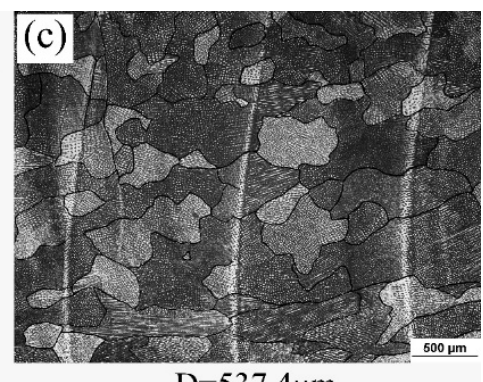

$\mathrm{D}=537.4 \mu \mathrm{m}$

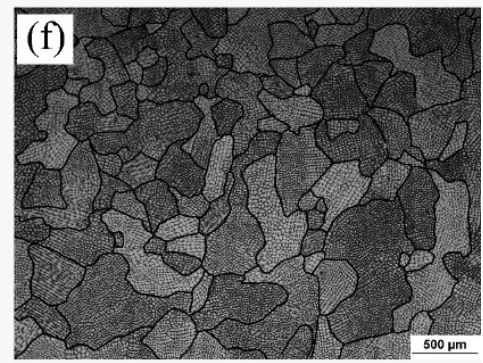

$\mathrm{D}=351.57 \mu \mathrm{m}$

Figure 14. Metallographic of weld center of parallel section at different pulse frequencies: (a) $1 \mathrm{~Hz}$, (b) $3 \mathrm{~Hz}$, (c) $5 \mathrm{~Hz}$, (d) $7 \mathrm{~Hz},(\mathbf{e}) 10 \mathrm{~Hz}$, (f) $15 \mathrm{~Hz}$.

As shown in Figure 15, some particles were distributed at the cellular grain's boundaries near 304L under SEM observation. The results of EDS analysis indicated that the particle's main chemical compositions were $\mathrm{C}, \mathrm{Fe}, \mathrm{Cr}$, and Ni. According to XRD results, the particle should be $\mathrm{M}_{23} \mathrm{C}_{6}$.
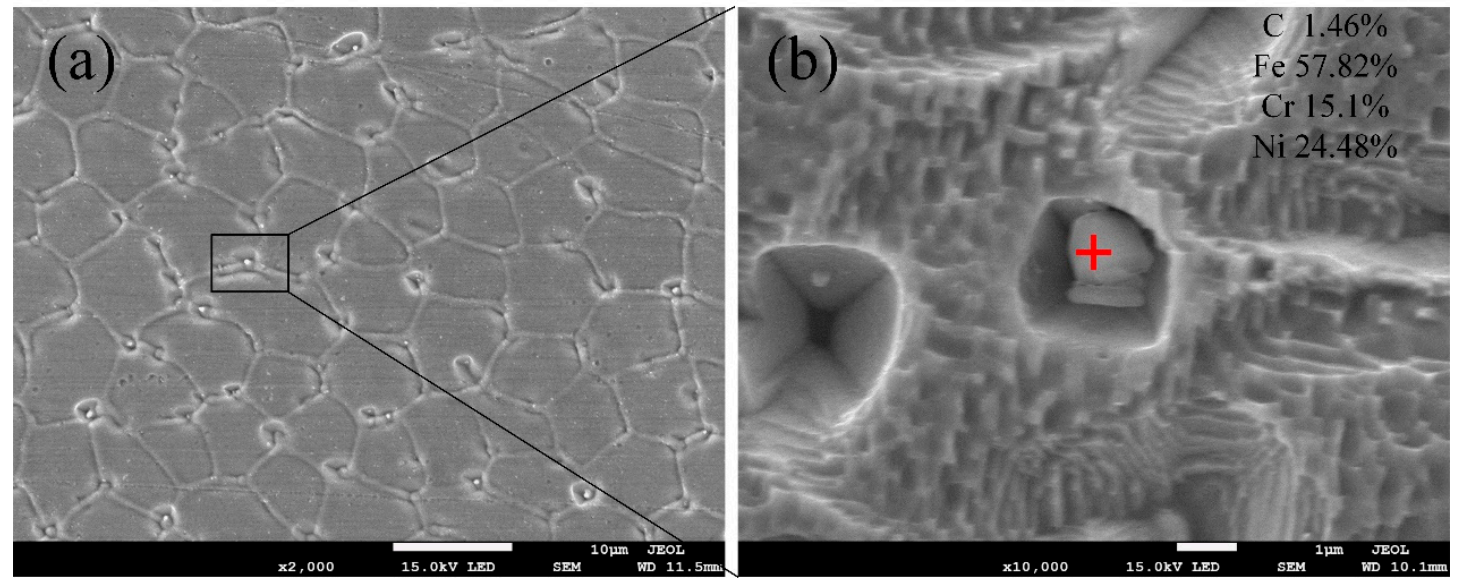

Figure 15. (a) Carbides at the grain boundaries and (b) High-magnification micrograph of the carbide.

Fe-36Ni and 304L have thermal conductivity, and the heat accumulation makes the temperature of the base material gradually increase with the progress of welding [33], which resulting in weld center can maintain a high temperature for a long time. So that the composition fluctuation at the boundary of cell crystal is large enough, and the carbide is enough to nucleate, so that a large number of precipitations occur. 


\subsection{Microhardness}

Figure 16 indicates that the microhardness of the $\mathrm{FZ}$ varied in a small range with the increase of the pulse frequency, and the average microhardness of the $\mathrm{FZ}$ at $1 \mathrm{~Hz}, 3 \mathrm{~Hz}, 5 \mathrm{~Hz}, 7 \mathrm{~Hz}, 10 \mathrm{~Hz}$ and 15 $\mathrm{Hz}$ was $110 \mathrm{HV}_{1}, 126 \mathrm{HV}_{1}, 114 \mathrm{HV}_{1}, 121 \mathrm{HV}_{1}, 136 \mathrm{HV}_{1}$ and $112 \mathrm{HV}_{1}$, respectively. The grain size in the heat-affected zone on the Fe-36Ni side is larger and the hardness of this area is lower.

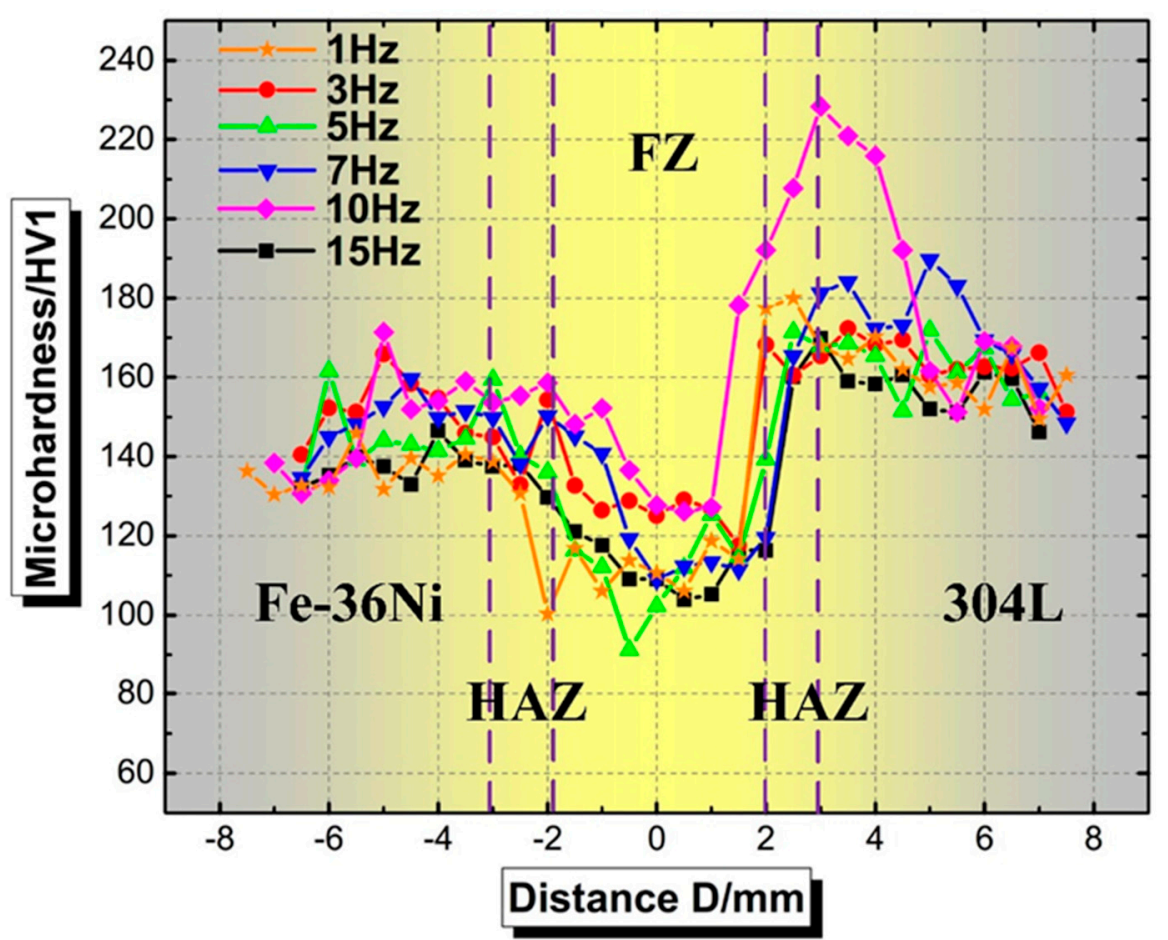

Figure 16. Microhardness distribution of Fe-36Ni/304L lap joints at different pulse frequencies.

The influence of the HAZ on the mechanical properties of the joint is through the hardening and softening caused by the welding thermal cycle. For the heat-affected zone in the 304L side, the microhardness tends to increase with increasing distance from the center of the weld and reached up to a maximum hardness of $164 \mathrm{HV} 1$. Rogalski et al. [34], studied the mechanical and microstructural of Incoloy 800 HT and austenitic stainless steel 304L dissimilar joints manufactured by gas tungsten arc welding, it is found that the hardness of the HAZ near 304L decreases, which results from the structure transform to $\delta$ ferrite. However, Shakil M. et al. [7], studied the welding of 690 alloy and 304L dissimilar alloys via electron beam welded, it is found there doesn't exist hardness decreases. The hardness test results of this study also did not find a decrease in the hardness on the 304L side. In summary, the main reason for the changes in the mechanical properties of the HAZ near 304L is the $\delta$ ferrite transformation caused by thermal cycling. The pulsed tungsten arc welding process has a small heat input and short high temperature residence time, which inhibits $\delta$ ferrite transformation.

Although the grains of FZ were refined with increasing the pulse frequency, the grains were still were relatively coarser than those of the parent materials $(27.97 \mu \mathrm{m}$ of Fe-36Ni and $17.23 \mu \mathrm{m}$ of $304 \mathrm{~L})$, resulting in the lowest hardness of the FZ.

\subsection{Tensile Properties}

The Table 4 shows the tensile test results for the welded joints obtained at different pulse frequencies. All tensile samples fractured at weld roots, which can be explained for two reasons. On the one hand, the lap joint leads to the stress concentration at the weld root under tensile load. On the other hand, the inhomogeneous distribution of the weld microstructure and the coarse austenite 
grains leads to the decrease of the joint performance. As shown in Figure 17, the average fracture tensile force $(\mathrm{F})$ increased with increasing the pulse frequency, and the maximum is $11.95 \mathrm{kN}$ when the pulse frequency was $15 \mathrm{~Hz}$. According to relevant reference [35], the strengnth of Fe-36Ni is $430 \mathrm{Mpa}$ (according to the tensile samples' size used in this study, the Fe-36Ni strength is converted to 12040 $\mathrm{kN})$. When the pulse frequency is $15 \mathrm{~Hz}$, the $\mathrm{F}$ of the joint is decreased by $0.7 \%$ compared to Fe-36Ni. The increase in $\mathrm{R}$ reduced the curvature of the force streamline under the tensile load, resulting in the reduction of the stress concentration [36]. Although the weld grain size decreased with the increase of pulse frequency, the hardness results indicated that the effect of grain size on tensile properties was limited. Figure 17 shows that there is a strong correlation between $R$ and $F$, which means that $R$ is the main factor determining the maximum tensile force of the lap joint.

Table 4. Results of the tensile tests.

\begin{tabular}{ccc}
\hline Sample & $\boldsymbol{F ( k N )}$ & $\begin{array}{c}\text { Fracture } \\
\text { Location }\end{array}$ \\
\hline $1 \mathrm{~Hz}$ & 10.85 & Weld Root \\
$3 \mathrm{~Hz}$ & 11.14 & Weld Root \\
$5 \mathrm{~Hz}$ & 11.01 & Weld Root \\
$7 \mathrm{~Hz}$ & 11.13 & Weld Root \\
$10 \mathrm{~Hz}$ & 11.15 & Weld Root \\
$15 \mathrm{~Hz}$ & 11.95 & Weld Root \\
\hline
\end{tabular}

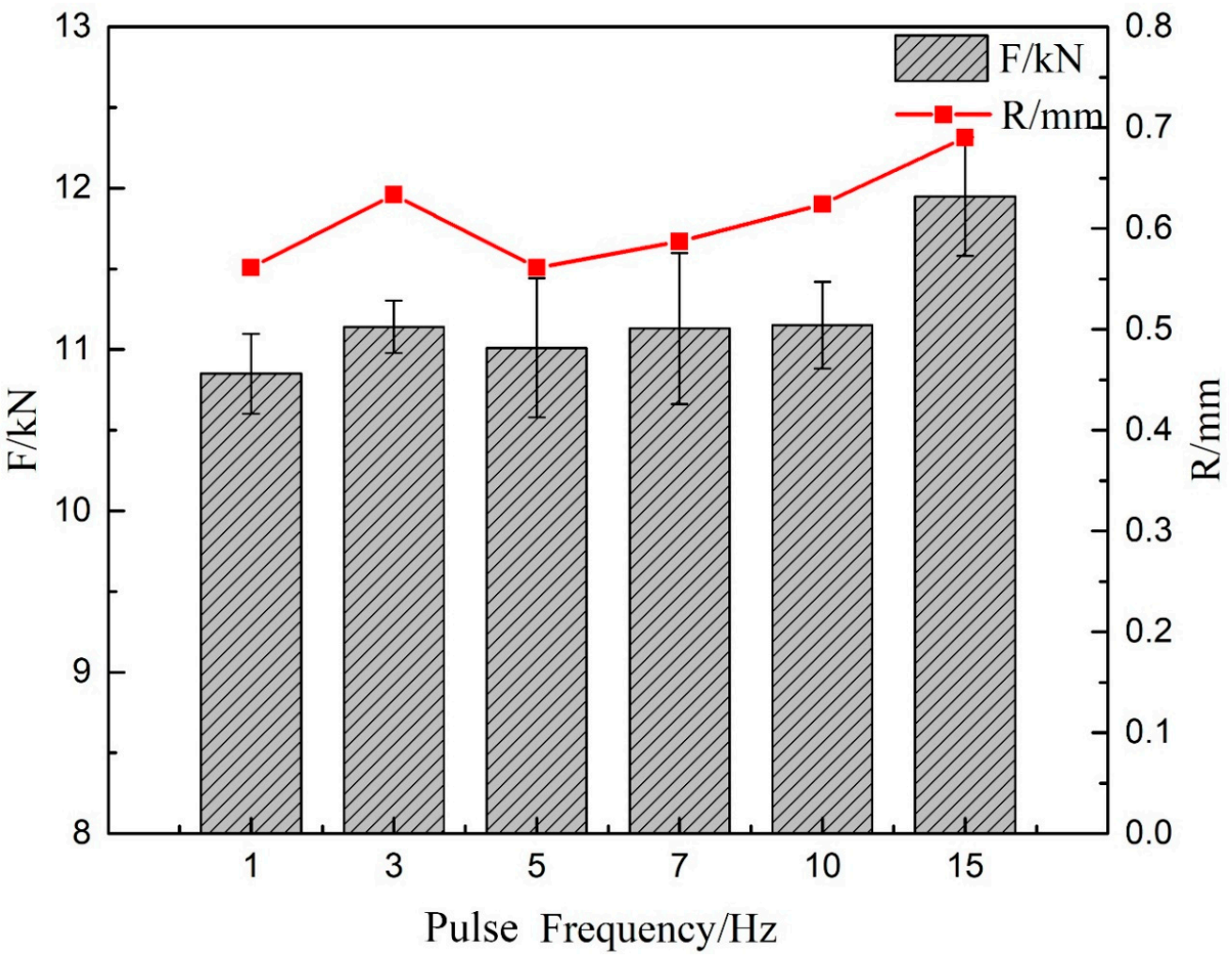

Figure 17. $F$ and feature size $R$ at different pulse frequencies.

Figure 18 shows the fracture morphologies of the lap joints at $3 \mathrm{~Hz}$ and $10 \mathrm{~Hz}$. There are many traces of plastic deformation at the fracture, and sliding and necking areas are obvious, exhibiting a typical plastic fracture as shown in Figure 18a,d. The micro fracture morphology is shown in Figure 18b-f. The elongation of dimples on the two fracture surfaces indicates that the lap joint was subjected to shear force during tensile process. The small fracture zone and sparse dimples on both sides indicate poor ductility of lap joint. 

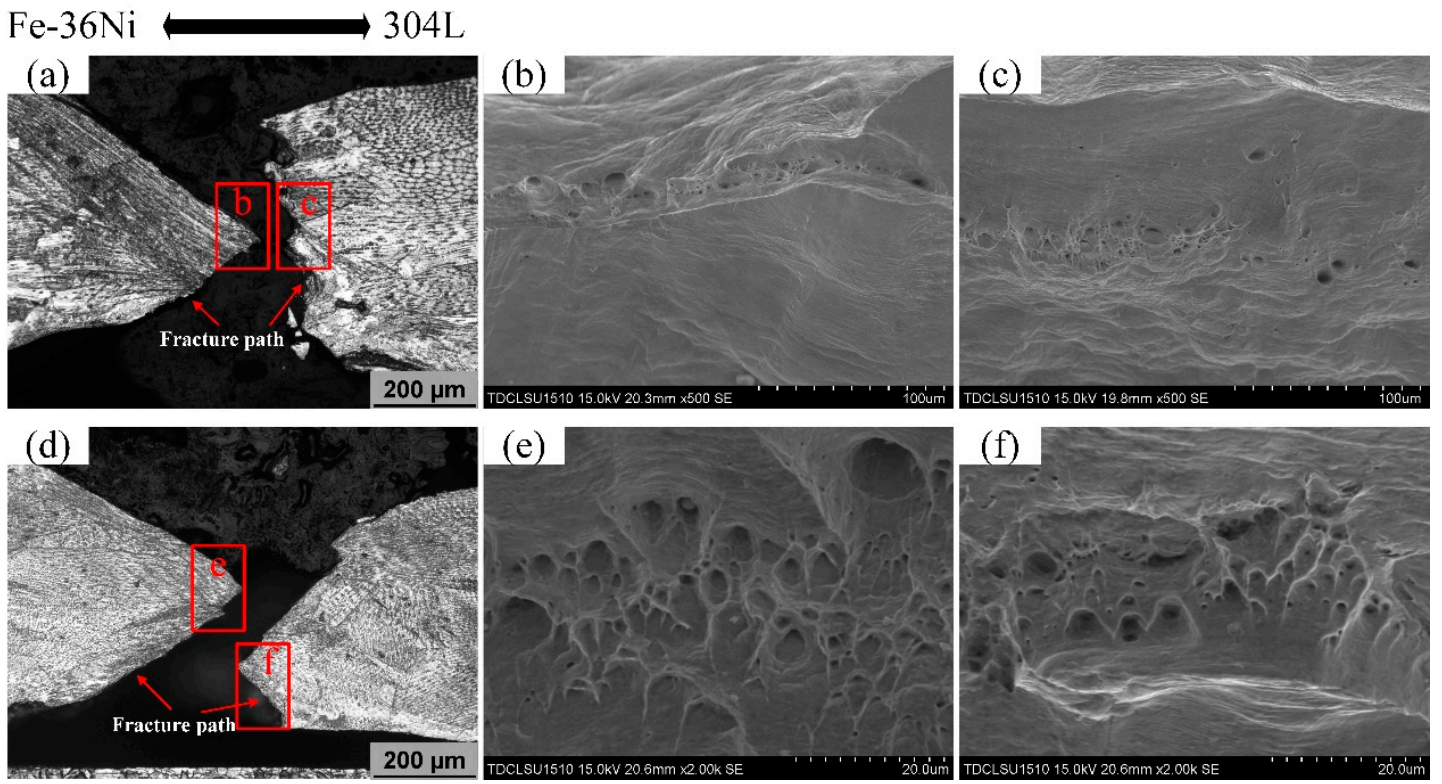

Figure 18. Weld fracture metallography and fracture morphology: (a) Fracture cross section at $3 \mathrm{~Hz}$, (b) Fracture morphology of the left side of the fracture (low magnification), (c) Fracture cross section at $3 \mathrm{~Hz},(\mathbf{d})$ Fracture cross section at $10 \mathrm{~Hz}$, (e) Fracture morphology of the left side of the fracture (high magnification), (f) Fracture morphology of the right side of the fracture (high magnification).

\section{Conclusions}

The pulse tungsten argon arc welding process can be used to connect Fe-36Ni to 304L dissimilar metals. The microstructure and mechanical properties of Fe-36Ni/304L heterogeneous lap joints with different pulse frequencies were studied. Concluded as follow:

(1) There are no visible defects such as void and cracks in the Fe-36Ni/304L lap joint.

(2) The feature size $L a$ and $P$ changed slightly, while $R$ showed an increasing trend and $\alpha$ showed

(3) A decreasing trend with the increase of pulse frequency.

(4) Fusion zone is mainly composed of $\gamma$ phase and $\mathrm{M}_{23} \mathrm{C}_{6}$, and $\mathrm{M}_{23} \mathrm{C}_{6}$ particles are distributed on the grain boundaries of the cells.

(5) The microhardness of the fusion zone is the lowest in the entire welded joint, with an average hardness between $110 \mathrm{HV}_{1}$ and $136 \mathrm{HV}_{1}$.

(6) The tensile force of Fe-36Ni/304L lap joint has a high positive correlation with the characteristic dimension $\mathrm{R}$. The average maximum tensile force is $11.95 \mathrm{kN}$ when the pulse frequency is $15 \mathrm{~Hz}$.

Author Contributions: Conceptualization, Q.W. and J.S.; methodology, S.H., G.Z. and J.Z.; software, Q.W.; validation, J.S; formal analysis, Q.W.; investigation, J.S.; resources, S.H. and G.Z.; data curation, J.S.; writing-original draft, Q.W.; writing-review \& editing, Q.W. and J.S. All authors have read and agreed to the published version of the manuscript.

Funding: This research was funded by National Natural Science Foundation of China: 51575381.

Acknowledgments: The authors would like to acknowledge the materials provided by Baosteel Special Steel Co., Ltd.

Conflicts of Interest: The authors declare no conflict of interest. 


\section{References}

1. Park, W.S.; Chun, M.S.; Han, M.S.; Kim, M.H.; Lee, J.M. Comparative study on mechanical behavior of low temperature application materials for ships and offshore structures: Part I-Experimental investigations. Mater. Sci. Eng. A 2011, 528, 5790-5803. [CrossRef]

2. Zhan, X.; Meng, Y.; Zhou, J.; Qi, C.; Zhang, C.; Gu, D. Quantitative research on microstructure and thermal physical mechanism in laser melting deposition for Invar alloy. J. Manuf. Process. 2018, 31, $221-231$. [CrossRef]

3. Mirshekari, G.R.; Tavakoli, E.; Atapour, M.; Sadeghian, B. Microstructure and corrosion behavior of multipass gas tungsten arc welded 304L stainless steel. Mater. Des. 2014, 55, 905-911. [CrossRef]

4. Baghjari, S.H.; AkbariMousavi, S.A.A. Experimental investigation on dissimilar pulsed Nd: YAG laser welding of AISI 420 stainless steel to kovar alloy. Mater. Des. 2014, 57, 128-134. [CrossRef]

5. Wu, S.; Ju, Y.; Lin, J.; Fu, Y. Numerical simulation and experiment verification of the static boil-off rate and temperature field for a new independent type B liquefied natural gas ship mock up tank. Appl. Therm. Eng. 2020, 712, 115-265. [CrossRef]

6. Li, D.L. Study on Automatic TIG Welding of Invar Alloy at Vertical Position. Master's Thesis, Tianjin University, Tianjin, China, 2016.

7. Shakil, M.; Ahmad, M.; Tariq, N.H.; Hasan, B.A.; Akhter, J.I.; Ahmed, E.; Mehmood, M.A.; Choudhry, M.A.; Igbal, M. Microstructure and hardness studies of electron beam welded Inconel 625 and stainless steel 304L. Vacuum 2014, 110, 121-126. [CrossRef]

8. Zhao, D.S.; Huang, Z.Y.; Liu, Y.J.; Miao, T. A Study of the Effect of Post-Heating Pulse on Hot Cracking Susceptibility in Pulsed Laser Welding of Invar Alloy. J. Ship Prod. Des. 2019, 35, 338-343. [CrossRef]

9. Wei, K.; Yang, Q.D.; Ling, B.; Yang, X.; Xie, H.; Qu, Z.; Fang, D. Mechanical properties of Invar 36 alloy additively manufactured by selective laser melting. Mater. Sci. Eng. A 2020, 772, 138799. [CrossRef]

10. Ni, J.M.; Li, Z.G.; Wu, Y.X. Hot tearing susceptibility of high speed laser welding invar sheet. Chin. J. Lasers 2011, 38, 82-86.

11. Cheepu, M.; Venkateswarlu, D.; Rao, P.N.; Muthupandi, V.; Sivaprasad, K.; Che, W.S. Microstructure Characterization of Superalloy 718 during Dissimilar Rotary Friction Welding. Mater. Sci. Forum 2019, 969, 211-217. [CrossRef]

12. Yan, F.; Fang, X.; Chen, L.; Wang, C.; Zhao, J.; Chai, F.; Wang, W. Microstructure evolution and phase transition at the interface of steel/Al dissimilar alloys during Nd: YAG laser welding. J. Opt. Laser Technol. 2018, 108, 193-201. [CrossRef]

13. Naffakh, H.; Shamanian, M.; Ashrafizadeh, F. Microstructural evolutions in dissimilar welds between AISI 310 austenitic stainless steel and Inconel 657. J. Mater. Sci. 2010, 45, 2564-2573. [CrossRef]

14. Montanari, R.; Filacchioni, G.; Riccardi, B.; Tata, M.E.; Costanza, G. Characterization of Eurofer-97 TIG-welded joints by FIMEC indentation tests. J. Nucl. Mater. 2004, 329-333, 1529-1533. [CrossRef]

15. Lee, H.T.; Lin, Y.D. Microstructure and corrosion behaviour of alloy 690-SUS 304L butt joints formed by electron beam welding. Sci. Technol. Weld. Join. 2006, 11, 650-656. [CrossRef]

16. Guo, X.; Liu, W.; Wang, C. Numerical Analysis of Elastic-Plastic Deformation Evolution and Fracture Behavior in Tensile Process of Laser Lap Welded 301L Joints. Chin. J. Lasers 2018, 3, 54-67.

17. Wang, H.; Hu, S.; Shen, J.; Li, D.; Lu, J. Effect of duty cycle on microstructure and mechanical properties of pulsed GTAW lap joint of Invar. J. Mater. Process. Technol. 2017, 243, 481-488. [CrossRef]

18. Rahimi, A.; Shamanian, M. The PC-GTAW of Ti-6Al-4V Thin Sheets and Its Effects on Mechanical and Microstructural Properties. Metallogr. Microstruct. Anal. 2019, 8, 871-879. [CrossRef]

19. Moganraj, A.; Devendranath, R.K.; Arivazhagan, N. Effect of Continuous and Pulsed Current on the Metallurgical and Mechanical Properties of Gas Tungsten Arc Welded AISI 4340 Aeronautical and AISI 304 L Austenitic Stainless Steel Dissimilar Joints. Mater. Res. 2015, 18, 59-77.

20. Ramkumar, K.D.; Joshi, V.; Pandit, S.; Agrawal, M.; Kumar, O.S.; Periwal, S.; Arivazhagan, N. Investigations on the microstructure and mechanical properties of multi-pass pulsed current gas tungsten arc weldments of Monel 400 and Hastelloy C276. Mater. Des. 2014, 64, 775-782. [CrossRef]

21. Feng, J.; Zhang, H.; He, P. The CMT short-circuiting metal transfer process and its use in thin aluminium sheets welding. Mater. Des. 2009, 30, 1850-1852. [CrossRef] 
22. Joseph, A.; Harwig, D.; Farson, D.F.; Richardson, R. Measurement and calculation of arc power and heat transfer efficiency in pulsed gas metal arc welding. Sci. Technol. Weld. Join. 2003, 8, 400-406. [CrossRef]

23. Madadi, F.; Ashrafizadeh, F.; Shamanian, M. Optimization of pulsed TIG cladding process of stellite alloy on carbon steel using RSM. J. Alloy Compd. 2011, 510, 71-77. [CrossRef]

24. Liu, J.W.; Rao, Z.H.; Liao, S.M.; Tsai, H.L. Numerical investigation of weld pool behaviors and ripple formation for a moving GTA welding under pulsed currents. Int. J. Heat Mass Transf. 2015, 91, 990-1000. [CrossRef]

25. Zhang, Y.; Lu, F.; Wang, H.P.; Wang, X.; Cui, H.; Tang, X. Reduced hot cracking susceptibility by controlling the fusion ratio in laser welding of dissimilar Al alloys joints. J. Mater. Res. 2015, 30, 993-1001. [CrossRef]

26. Muthupandi, V.; Bala Srinivasan, P.; Seshadri, S.K.; Sundaresan, S. Effect of weld metal chemistry and heat input on the structure and properties of duplex stainless steel welds. Mater. Sci. Eng. A 2003, 358, 9-16. [CrossRef]

27. Kou, S. Welding Metallurgy, 2nd ed.; John Wiley \& Sons, Ltd.: Hoboken, NJ, USA, 2003; pp. 145-169.

28. Ding, K.; Ji, H.J.; Liu, X.; Wang, P.; Zhang, Q.L.; Li, X.H.; Gao, Y.L. Prevention of carbon migration in 9\% $\mathrm{Cr} / \mathrm{CrMoV}$ dissimilar welded joint by adding tungsten inert gas overlaying layer. J. Iron Steel Res. Int. 2018, 25, 847-853. [CrossRef]

29. Zhang, X.H.; Chen, J.Q.; Zhang, K.; Chen, H. Study on Grain Refinement of Nickel-Based Filler Metal 52M Microstructure by Pulse TIG Welding. In Proceedings of the International Conference on Mechatronics Engineering \& Information Technology (ICMEIT 2017), Dalian, China, 13-14 May 2017.

30. Li, N.; Zhang, L.; Zhang, R.; Yin, P.; Xing, H.; Wu, H. Research on Grain Refinement in Hypoeutectic Al-Si Alloy during Solidification under an Alternating Electric Current Pulse. Metals 2019, 9, 571. [CrossRef]

31. Anbarasan, N.; Jerome, S.; Suresh, G.; Oyyaravelu, R. Effect of Pulse Frequency on Microstructural and Corrosion Properties of Inconel 718 Gas Tungsten Arc Weldments. Trans. Indian Inst. Met. 2019, 72, 1299-1311. [CrossRef]

32. Shao, L.; Wu, S.; Datye, A.; Zhao, H.; Petterson, M.; Peng, W. Microstructure and mechanical properties of ultrasonic pulse frequency tungsten inert gas welded Ti-22Al-25Nb (at.\%) alloy butt joint. J. Mater. Process. Technol. 2018, 259, 416-423. [CrossRef]

33. Zhao, G.; Du, J.; Wei, Z.; Geng, R.; Xu, S. Numerical analysis of arc driving forces and temperature distribution in pulsed TIG welding. J. Braz. Soc. Mech. Sci. Eng. 2019, 41, 1-9. [CrossRef]

34. Rogalski, G.; Świerczyńska, A.; Landowski, M.; Fydrych, D. Mechanical and microstructural characterization of tig welded dissimilar joints between 3041 austenitic stainless steel and incoloy 800HT nickel alloy. Metals 2020, 10, 559. [CrossRef]

35. Oh, D.J.; Kim, N.K.; Song, S.W.; Kim, Y.D.; Kim, M.H. Investigation of fatigue performance for new membrane-type LNG CCS at cryogenic temperature. Mar. Struct. 2018, 62, 90-105. [CrossRef]

36. Kelly, D.W.; Tosh, M.W. Interpreting load paths and stress trajectories in elasticity. Eng. Comput. 2000, 17, 117-135. [CrossRef]

(C) 2020 by the authors. Licensee MDPI, Basel, Switzerland. This article is an open access article distributed under the terms and conditions of the Creative Commons Attribution (CC BY) license (http://creativecommons.org/licenses/by/4.0/). 